\title{
Stalk and sucrose yield in response to nitrogen fertilization of sugarcane under reduced tillage
}

\author{
Caio Fortes ${ }^{(1)}$, Paulo César Ocheuze Trivelin(1), André César Vitti(2), Rafael Otto(3), \\ Henrique Coutinho Junqueira Franco ${ }^{(4)}$ and Carlos Eduardo Faroni ${ }^{(5)}$
}

\begin{abstract}
(1)Universidade de São Paulo (USP), Centro de Energia Nuclear na Agricultura, Caixa Postal 96, CEP 13400-970 Piracicaba, SP, Brazil. E-mail: caio.fortes@bp.com, pcotrive@cena.usp.br ${ }^{(2)}$ Agência Paulista de Tecnologia dos Agronegócios, Caixa Postal 28, CEP 13400-970 Piracicaba, SP, Brazil. E-mail: acvitti@apta.sp.gov.br (3)USP, Escola Superior de Agricultura Luiz de Queiroz, Departamento de Ciência do Solo, Caixa Postal 9, CEP 13418-900 Piracicaba, SP, Brazil. E-mail: rotto@usp.br ${ }^{(4)}$ Laboratório Nacional de Ciência e Tecnologia do Bioetanol, Rua Giuseppe M. Scolfaro, № 10.000, CEP 13083-970 Campinas, SP, Brazil. E-mail: henrique.franco@bioetanol.org.br ${ }^{(5)} \mathrm{Agrolatino}$ Fertilizantes Especiais, Rua Elias Raimundo de Brito, no596, CEP 15991-151 Matão, SP, Brazil. E-mail: faroni@agrolatino.com.br
\end{abstract}

\begin{abstract}
The objective of this work was to evaluate the agroindustrial production of sugarcane (millable stalks and sucrose yield) after successive nitrogen fertilizations of plant cane and ratoons in a reduced tillage system. The experiment was carried out at Jaboticabal, SP, Brazil, on a Rhodic Eutrustox soil, during four consecutive crop cycles (March 2005 to July 2009). Plant cane treatments consisted of N-urea levels (control, 40, 80, and $120 \mathrm{~kg} \mathrm{ha}^{-1} \mathrm{~N}+120 \mathrm{~kg} \mathrm{ha}^{-1} \mathrm{P}_{2} \mathrm{O}_{5}$ and $\mathrm{K}_{2} \mathrm{O}$ in furrow application). In the first and second ratoons, the plant cane plots were subdivided in $\mathrm{N}$-ammonium nitrate treatments (control, 50, 100, and $150 \mathrm{~kg} \mathrm{ha}^{-1} \mathrm{~N}+150 \mathrm{~kg} \mathrm{ha}^{-1} \mathrm{~K}_{2} \mathrm{O}$ as top dressing over rows). In the third ratoon, $\mathrm{N}$ fertilization was leveled to $100 \mathrm{~kg} \mathrm{ha}^{-1}$ in all plots, including controls, to detect residual effects of previous fertilizations on the last crop's cycle. Sugarcane ratoon was mechanically harvested. A weighing truck was used to evaluate stalk yield (TCH), and samples were collected in the field for analysis of sugar content (TSH). Increasing $\mathrm{N}$ doses and meteorological conditions promote significant responses in TCH and TSH in cane plant and ratoons, in the average and accumulated yield of the consecutive crop cycles.

Index terms: Saccharum, agroindustrial production, biomass, crop residues, subsoiling, unburned cane.

\section{Produtividade de colmo e sacarose em resposta à adubação nitrogenada da cana-de-açúcar, sob preparo reduzido}

Resumo - O objetivo deste trabalho foi avaliar a produtividade agroindustrial de cana-de-açúcar (produtividades de colmos e sacarose) após sucessivas adubações nitrogenadas de cana-planta e soqueiras, em sistema de preparo reduzido. O experimento foi conduzido em Jaboticabal, SP, em um Latossolo Vermelho eutrófico durante quatro ciclos agrícolas consecutivos (março de 2005 a julho de 2009). Os tratamentos de cana-planta consistiram de doses de N-ureia (controle, 40, 80 e $120 \mathrm{~kg} \mathrm{ha}^{-1} \mathrm{de} \mathrm{N}+120 \mathrm{~kg} \mathrm{ha}^{-1}$ de $_{2} \mathrm{O}_{5}$ e $\mathrm{K}_{2} \mathrm{O}$ no sulco de plantio). Na primeira e na segunda soqueiras, as parcelas de cana-planta foram subdivididas em tratamentos de N-nitrato de amônio (controle, 50, 100 e $150 \mathrm{~kg} \mathrm{ha}^{-1}$ de $\mathrm{N}+150 \mathrm{~kg} \mathrm{ha}^{-1}$ de $\mathrm{K}_{2} \mathrm{O}$, sobre as fileiras de cana). $\mathrm{Na}$ terceira soqueira, a adubação com $\mathrm{N}$ foi de $100 \mathrm{~kg} \mathrm{ha}^{-1} \mathrm{em}$ todas as parcelas, inclusive nos controles, para detectar efeitos residuais das fertilizações anteriores na produtividade do último ciclo. Os colmos de cana foram colhidos mecanicamente. Utilizou-se caminhão instrumentado com balança para avaliação da produtividade de colmos (TCH), e amostras retiradas no campo para análise da quantidade de açúcar dos colmos (TSH). As doses crescentes de $\mathrm{N}$ e as condições meteorológicas proporcionam respostas significativas na TCH e na TSH da cana-planta e das soqueiras, na média e na produção acumulada dos ciclos agrícolas consecutivos.

Termos para indexação: Saccharum, produtividade agroindustrial, biomassa, resíduos culturais, subsolagem, cana crua.

\section{Introduction}

Nitrogen is an essential nutrient for food and bioenergy production that can be highly pollutant to water bodies and the atmosphere if not properly used in agriculture (Liu et al., 2010). Sugarcane extracts 100 to $300 \mathrm{~kg} \mathrm{ha}^{-1} \mathrm{~N}$ from soil to produce $100 \mathrm{Mg} \mathrm{ha}^{-1}$ of millable stalks in each cycle (Trivelin et al., 2002; Cantarella et al., 2007). Significant yield responses to $\mathrm{N}$ fertilization have been reported, as well as possible residual effects of repeated $\mathrm{N}$ applications on subsequent sugarcane cycles (Wiedenfeld, 1998, 2000; Orlando Filho et al., 1999; Vitti et al., 2007; Dourado-Neto et al., 2010). Mineral N can also 
enhance root growth within the crop residues of unburned harvested sugarcane and reduce the C:N ratio of those residues, building a nutritional $\mathrm{N}$ reserve on soil organic matter (SOM) and in crop underground parts (Vitti et al., 2007; Fortes et al., 2011).

Green cane management or harvesting without burning is a current practice in producing countries worldwide used to reduce environmental impacts and to prevent respiratory illnesses related to airborne ash particles in surrounding neighborhoods (Cançado et al., 2006). This cropping method preserves 5 to $20 \mathrm{Mg} \mathrm{ha}^{-1}$ of crop residues (dry leaves, tops, and previous crop ratoons) on soil surface, which comprise an important source of carbon and nutrients that can potentially increase sugarcane lifespan and yields due to the reduction of $\mathrm{N}$ losses throughout the soil-plant system (Trivelin et al., 2002; Vitti et al., 2007; Hemwong et al., 2009). However, residues from green harvested sugarcane also decrease the rate of SOM oxidation and soil acidification, enhance erosion control, and increase soil biological activity and water infiltration (Dourado Neto et al., 2010; Rossetto et al., 2010).

Global models suggest that recovery rates of the overall $\mathrm{N}$ applied in agriculture are around $55 \%$, being $35 \%$ in harvested products and $20 \%$ in crop residues; but the latter are still underestimated in nutrient recycling in developing countries (Liu et al., 2010). Therefore, $\mathrm{N}$ fertilization management is a challenge beyond the replacement of crop requirements and must take into account the agronomic and environmental impacts of mineral fertilizers and crop residues on the agroecosystems, as well as in $\mathrm{C}, \mathrm{N}$, and other nutrient balances in soil-plant-atmosphere (Dourado Neto et al., 2010; Fortes et al., 2011; Thorburn et al., 2011).

Reduced tillage consists of a soil conservation system, which preserves part of the crop residues left on soil surface after crop renewal, enables higher erosion control (Stolf, 1985), and reduces nutrient losses (Hemwong et al., 2009). The increasing costs of high-yielding sugarcane production are mainly driven by fossil fuel consumption, both in mechanized operations and $\mathrm{N}$ fertilizer production. Therefore, conservation practices, such as reduced tillage and green harvested sugarcane, are mandatory to support economic and environmental sustainability and for a better utilization of $\mathrm{N}$ by sugarcane (Fortes et al., 2011; Thorburn et al., 2011).
The objective of this work was to evaluate the agroindustrial production of sugarcane (ratoon and sucrose yield) after successive nitrogen fertilizations of plant cane and ratoons in a reduced tillage system.

\section{Materials and Methods}

The experiment was carried out in the county of

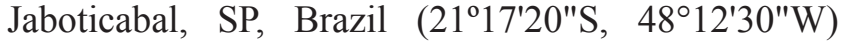
on a clayey Latossolo Vermelho eutrófico (Rhodic Eutrustox), according to the Brazilian and American soil classification systems, respectively (Santos et al., 2006; Soil Survey Staff, 2006). This area had been previously cropped with sugarcane, during seven years, without burning prior to harvest, as reported by Vitti et al. (2011). The soil was chemically and physically characterized according to Raij et al. (2001), and the $0-0.25$ and $0.25-0.50 \mathrm{~m}$ soil layers indicated the following results: 5.2 and $5.6 \mathrm{pH}\left(\mathrm{CaCl}_{2}\right)$; 31 and $18 \mathrm{~g} \mathrm{dm}^{-3}$ of SOM; 42 and $12 \mathrm{mg} \mathrm{dm}^{-3} \mathrm{P}$; 3.1 and $0.5 \mathrm{mmol}_{\mathrm{c}} \mathrm{dm}^{-3} \mathrm{~K} ; 31$ and $24 \mathrm{mmol}_{\mathrm{c}} \mathrm{dm}^{-3} \mathrm{Ca} ; 9$ and $6 \mathrm{mmol}_{\mathrm{c}} \mathrm{dm}^{-3} \mathrm{Mg} ; 77.4$ and $53 \mathrm{mmol}_{\mathrm{c}} \mathrm{dm}^{-3} \mathrm{CEC}$, respectively.

The adopted soil preparation system was reduced tillage. Therefore, the previous ratoon was eradicated with herbicide, followed by a single subsoiling operation, and the subsequent ratoon crops were conducted without interow scarification after each harvest.

Sugarcane was planted on $3 / 2 / 2005$, with $1.5 \mathrm{~m}$ spacing between rows, and $120 \mathrm{~kg} \mathrm{ha}^{-1} \mathrm{P}_{2} \mathrm{O}_{5}$ and $\mathrm{K}_{2} \mathrm{O}$ were applied at planting (Espironello et al., 1996). A randomized complete block design was used, with four replicates $(48 \times 15 \mathrm{~m}$ rows) of $\mathrm{N}$-urea levels (control, 40, 80, and $120 \mathrm{~kg} \mathrm{ha}^{-1} \mathrm{~N}$ ), manually incorporated into the planting furrows immediately before the seed cane distribution. The planting population density was 20 viable buds per meter of the sugarcane variety SP81-3250 (Copersucar, 1995), which encompasses about $13 \%$ of the overall national sugarcane area due to its high suitability to mechanical green harvesting (Chapola et al., 2010).

After plant cane harvesting in 2006, the experiment was settled in a split-plot design; therefore, each N-urea level at plant cane was divided into four subplots (12x15 m rows), with four treatments - control (0), 50, 100 , and $150 \mathrm{~kg} \mathrm{ha}^{-1}$ of $\mathrm{N}$-ammonium nitrate, which were added to $150 \mathrm{~kg} \mathrm{ha}^{-1} \mathrm{~K}_{2} \mathrm{O}$ as $\mathrm{KCl}$ was applied 
in all subplots as top dressing. The first and second ratoons (2007 and 2008) received these treatments, whereas $\mathrm{N}$ fertilization in the third ratoon (2009) was leveled to $100 \mathrm{~kg} \mathrm{~N}+127 \mathrm{~kg} \mathrm{ha}^{-1} \mathrm{~K}_{2} \mathrm{O}$ during the whole trial (including controls) in order to assess probable residual effects of the previous $\mathrm{N}$ fertilizations on the last cycle's yield. In plant cane plots, sugarcane was manually cut without burning in August 2006, and the stalks contained in the eight central rows were weighed with a grab loader instrumented with load cell to evaluate crop yield (TCH).

In the ratoon plots, the four central rows were mechanically harvested without burning (first, second, and third ratoons on August 2007, July 2008, and July 2009, respectively), and TCH was obtained using a truck instrumented with a weighing scale belonging to the Centro de Tecnologia Canavieira, located at Piracicaba, SP, Brazil. The industrial quality (sucrose $\%$ and fiber $\%$ ) was obtained according to the Brazilian guidelines of sugarcane payment (Conselho dos Produtores de Cana-de-Açúcar, Açúcar e Álcool do Estado De São Paulo, 2006) by collecting samples of ten sequentially harvested stalks in each plot, which were processed in the cane payment laboratory of the São Martinho sugarmill, located at Pradópolis, SP, Brazil. Sugar yield (TSH) was obtained by multiplying crop yield (TCH) by the amount of sugar (sucrose \%) contained in the raw material. The ramaining rows of plant cane plots were mechanically harvested and provided adequate trash blanketing for upcoming crops.

Besides agroindustrial production, water balances of each crop cycle (plant cane and three ratoons) were assessed according to Allen et al. (1998), attempting to facilitate the detection of response differences among the $\mathrm{N}$ treatments after the evaluated cropping cycles. The considered water holding capacity of soil was $100 \mathrm{~mm}$ in the first $1.0 \mathrm{~m}$ soil layer, and meteorological data was obtained from an automatic weather station. The agroindustrial yields (TCH and TSH) of each cropping cycle (2006 to 2009) were subjected to analysis of variance and to regression analysis (at 1 or $5 \%$ probability) of the $\mathrm{N}$ applied in plant cane and ratoons.

\section{Results and Discussion}

No differences were observed in the weather patterns during the evaluated cycles, with periods of intense water stress due to high evapotranspiration rates and concentrated distribution of rainfall, respectively, in plant cane (2006) and in the first and second ratoons (2007 and 2008). The last crop cycle or third ratoon (2009) presented a better rainfall distribution and less severe evapotranspiration, which, together with the $\mathrm{N}$ levels previously applied, resulted in positive responses on the average yield $(\mathrm{TCH})$ observed in this cycle (Figure 1).

In general, there were significant responses of $\mathrm{TCH}$ and TSH due to the increasing $\mathrm{N}$ levels applied along the evaluated cropping cycles, and a linear response was detected for the plant cane crop (Figure 2). TSH responses were exclusively driven by $\mathrm{TCH}$, since the interactions between the $\mathrm{N}$ levels applied in plant cane and ratoons were not significant as well as the average sugar contents of the four evaluated crops (Table 1).

Korndörfer et al. (1997) also reported TCH increases in the plant cane of four sugarcane varieties with increasing levels of $\mathrm{N}$-urea $\left(0,30,60\right.$, and $\left.120 \mathrm{~kg} \mathrm{ha}^{-1}\right)$ in a clay loam Oxisol in the state of Minas Gerais, Brazil. Korndörfer et al. (2002) obtained $10 \mathrm{TCH}$ as an average increase in the sugarcane yield of seven varieties cropped on a clayey Ultisol in the north of the state of São Paulo, Brazil, using $60 \mathrm{~kg} \mathrm{ha}^{-1} \mathrm{~N}$ fertilization.

Franco et al. (2010) evaluated the responses of plant cane of that same variety, using the same $\mathrm{N}$-urea levels as those in the present work, but in two different sites in the state of São Paulo, and observed an increase in cane TCH only in the sandy soil, whereas in the clay loam this response was not evident. This lack of response could be related to the heavier soil tillage performed in the second site prior to planting, which could have led to a more pronounced $\mathrm{N}$ mineralization of SOM and, consequently, increased $\mathrm{N}$ availability to plants. Likewise, Wiedenfeld (1998, 2000) did not verify responses of plant cane to increasing $\mathrm{N}$ levels in Texas, which was attributed to the amount of $\mathrm{N}$ available in the soil, adequate for sugarcane nutrition.

Cantarella et al. (2007) reported that plant cane responses to $\mathrm{N}$ were erratic and only $30 \%$ out of the 74 trials conducted in the state of São Paulo presented significant responses. According to the authors, an economic $\mathrm{N}$ level for plant cane would be of nearly $75 \mathrm{~kg} \mathrm{ha}^{-1}$. Penatti \& Forti (1997) observed a higher frequency of response to $\mathrm{N}$ in 12 month sugarcane, planted in spring (September to November), than in 
18 month cane planted in summer, regardless of soil texture. These authors recommended that plant cane doses should be ruled by profitability, which, in this case, would be around $50 \mathrm{~kg} \mathrm{ha}^{-1} \mathrm{~N}$.

The soil fertility of this area (Eutrophic and clayey soil) could be classified as a high yielding environment for sugarcane, since the tropical conditions and the reduced tillage system, in which part of the crop residues had been preserved in soil after crop renewal, enabled a positive response of sugarcane to $\mathrm{N}$ levels (Figure 2). These results corroborate with Orlando Filho et al. (1999), who obtained linear responses
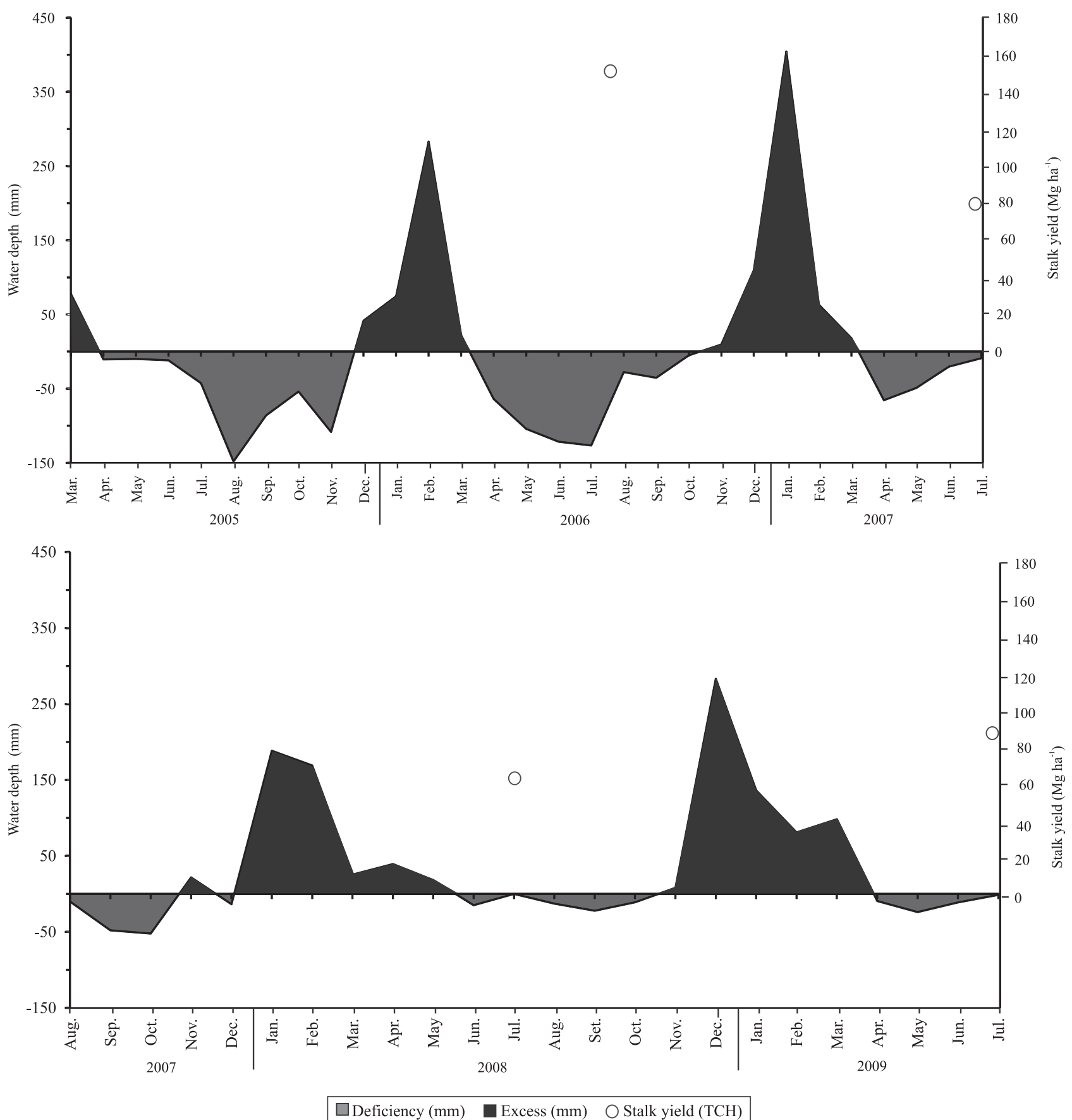

Figure 1. Water balances and average stalk yield ( $\mathrm{Mg} \mathrm{ha}^{-1}$ of millable stalks) of each sugarcane cycle from March 2005 to July 2009. Precipitation and evapotranspiration, respectively, for plant cane (1,752 and 1,283 mm), first ratoon $(1,719$ and $1,002 \mathrm{~mm})$, second ratoon $(1,372$ and $901 \mathrm{~mm})$, and third ratoon $(1,477$ and $821 \mathrm{~mm})$. 
of plant cane and ratoons of the variety SP71-1406, grown in an eutrophic soil, with increasing $\mathrm{N}$ levels up to $120 \mathrm{~kg} \mathrm{ha}^{-1}$. Besides Eutrophic soils and reduced tillage, the authors also emphasized that plant cane responses to $\mathrm{N}$ fertilization are expected in areas where sugarcane is planted for the first time.

Trivelin et al. (2002) found linear responses of the plant cane SP80-1842 on TCH with increasing levels of $\mathrm{N}$-urea $\left(0,30,60\right.$, and $\left.90 \mathrm{~kg} \mathrm{ha}^{-1}\right)$, but did not report differences on yield due to cane straw incorporation on a sandy soil in crop renewal. Although the plant cane can show responses to $\mathrm{N}$ fertilization in tropical conditions, this crop also accumulates $\mathrm{N}$ from other sources, such as soil organic matter (Dourado Neto et al., 2010) and biological $\mathrm{N}$ fixation by microorganisms (Boddey et al., 2003), which can decrease $\mathrm{N}$ response in this cycle.
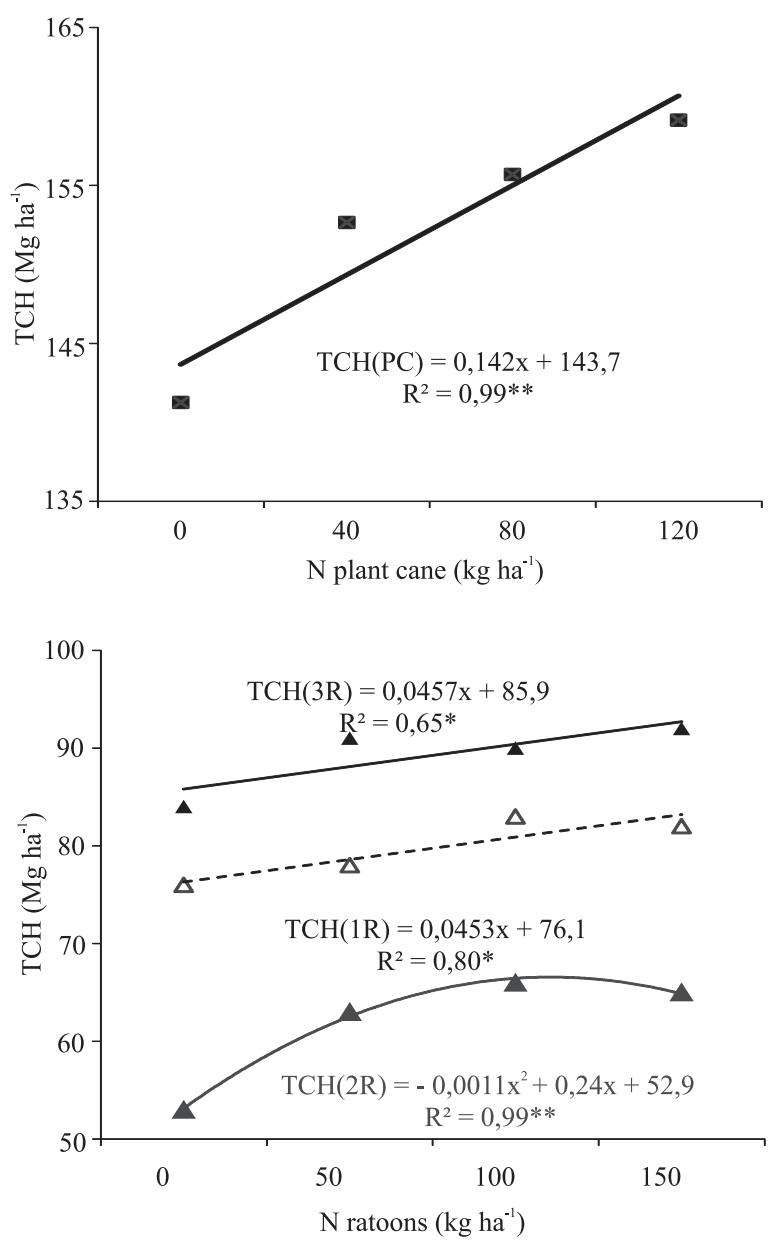

As in the plant cane cycle, the first and third ratoons (2007 and 2009, respectively) also presented linear responses on $\mathrm{TCH}$ to the applied $\mathrm{N}$, whereas the second ratoon (2008) showed a quadratic response (Figure 2). However, this cycle also provided the lowest TCH of the evaluated cycles (average of $62 \mathrm{Mg} \mathrm{ha}^{-1}$ ), mainly due to environmental constraints, including a period of approximately six months of water stress that occurred immediately after harvesting of the previous cycle (Figure 1), associated to an intense leafhopper (Mahanarva fimbriolata) attack at the end of this cropping cycle (Fortes, 2010).

Orlando Filho et al. (1994) also found that leafhopper attack was more intense in unburned harvested plots, which could have interfered on yield responses more than the $\mathrm{N}$ levels. Although restrictive yield conditions have been verified in the present work, $\mathrm{N}$ fertilization increased sugarcane $\mathrm{TCH}$ and yield, which reached
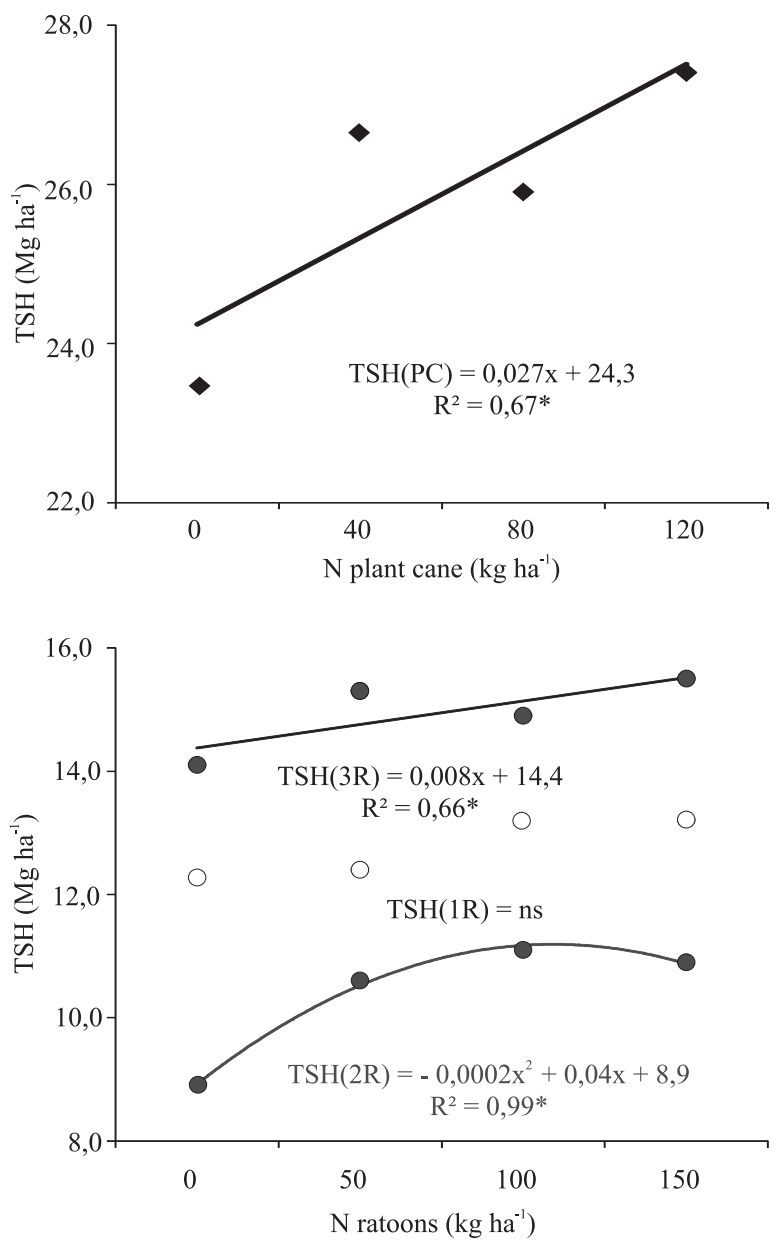

Figure 2. Agroindustrial yields related to N levels in plant cane (2006) and in the three consecutive ratoons (2007 to 2009). $\mathrm{TCH}$, crop yield of each year $\left(\mathrm{Mg} \mathrm{ha}^{-1}\right.$ of millable stalks); $\mathrm{TSH}$, sugar yield ( $\mathrm{Mg} \mathrm{ha}^{-1}$ of sucrose). PC, plant cane; ${ }^{\mathrm{n}} \mathrm{R}$, ratoons. 
its peak with $110 \mathrm{~kg} \mathrm{ha}^{-1}$ (Figure 2). This result is important because, in restrictive environmental or economic conditions, $\mathrm{N}$ fertilization should not be radically aborted, since it sustains the upcoming sugarcane cycles, as well as SOM, as pointed out by Vitti et al. (2007) and Dourado Neto et al. (2010).

In the third ratoon, in which all plots received $100 \mathrm{~kg} \mathrm{ha}^{-1} \mathrm{~N}$, the conditions were adequate for crop growth, with regular rainfall distribution and lower evapotranspiration rates (Figure 1). Consequently, a TCH recovery was observed in this cycle, with an average of $89 \mathrm{Mg} \mathrm{ha}^{-1}$, in addition to a linear response to the previously applied $\mathrm{N}$ levels in plant cane and in the first and second ratoons (Figures 1 and 2).

No significant interactions were observed between $\mathrm{N}$ fertilizations in any cycle; therefore, the $\mathrm{TCH}$ differences in the ratoons took into consideration the average of the plant cane factor (Fortes, 2010). However, the results obtained for $\mathrm{TCH}$ on the third ratoon (Figure 2) and the average of the four cycles (Figure 3) indicated that higher $\mathrm{N}$ doses applied on the previous cycles maintained the yield in this last cycle, which was confirmed by the absence of TCH recovery on the control replicates. According to Orlando Filho et al. (1999) and Vitti et al. (2007), the indirect effect of residual $\mathrm{N}$ of plant cane may reflect more intensely in the subsequent ratoons. The authors concluded that after 60 and $120 \mathrm{~kg} \mathrm{ha}^{-1} \mathrm{~N}$ on planting, the subsequent ratoons yielded 20 and $35 \%$ higher, respectively. Moreover, the green harvested sugarcane grown under reduced tillage can potentially deliver higher yields due to enhanced SOM conservation and nutrient cycling, as highlighted by Hemwong et al. (2009) and Fortes et al. (2011). On the average of four crops (2006 to 2009), the $\mathrm{N}$ rate that provided the highest yield was $121 \mathrm{~kg} \mathrm{ha}^{-1}$ (Figure 3).

Table 1. Average values of sugar content in sugarcane in the evaluated cycles ${ }^{(1)}$.

\begin{tabular}{lcccc}
\hline $\begin{array}{l}\mathrm{N} \text { treatment } \\
\left(\mathrm{kg} \mathrm{ha}^{-1}\right)\end{array}$ & PC (2006) & 1R (2007) & 2R (2008) & 3R (2009) \\
\hline 0 & 16.7 & 16.3 & 16.8 & 16.8 \\
40 or 50 & 17.5 & 16.1 & 16.8 & 16.8 \\
80 or 100 & 16.7 & 16.0 & 16.8 & 16.6 \\
120 or 150 & 17.2 & 16.1 & 16.8 & 16.9 \\
\hline Average & $17.0^{\text {ns }}$ & $16.1^{\text {ns }}$ & $16.8^{\text {ns }}$ & $16.8^{\text {ns }}$ \\
\hline
\end{tabular}

(1)PC, plant cane 2006; 1R, first ratoon 2007; 2R, second ratoon 2008; 3R, third ratoon 2009.
Although it was not observed in the present study, $\mathrm{N}$ fertilization can reduce sucrose content due to the dilution effect of higher moisture content on plant tissues and to the increased consumption of energy as a result of a more intense vegetative development (Wiedenfeld, 1998, 2000). This author concluded that, in the case of negative responses to $\mathrm{N}$ in the sugar content on sugarcane stalks, the $\mathrm{N}$ levels that maximize this factor are lower than those that provide the highest TCH. Therefore, the sugar yields (TSH) observed in the present work were linearly different among $\mathrm{N}$ treatments in plant cane and ratoons, due to the variation in cane yield per hectare $(\mathrm{TCH})$ (Figures 2 and 3), which is in accordance with findings
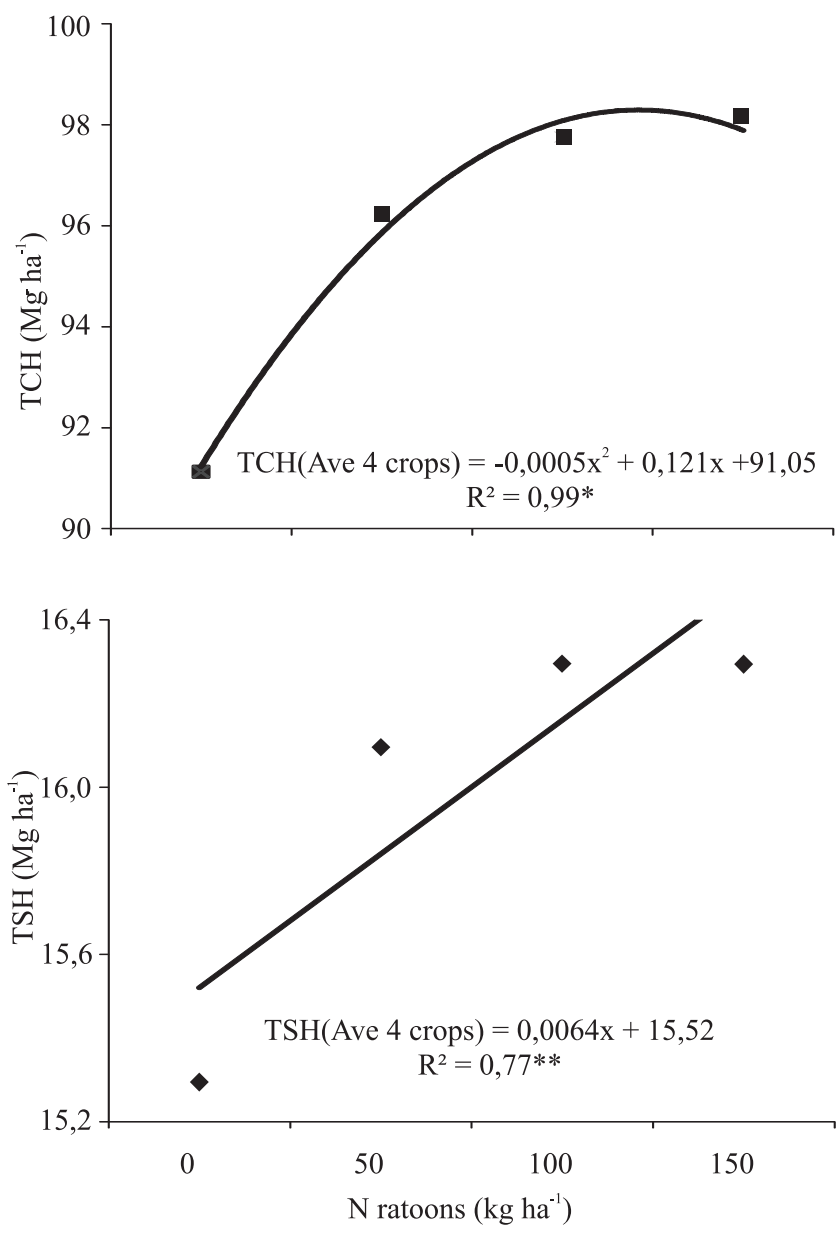

Figure 3. Average agroindustrial yields related to $\mathrm{N}$ levels applied on ratoons (2007 to 2009) and average yield of plant cane. TCH (Ave 4 crops), average crop yield of $\mathrm{PC}+1 \mathrm{R}+2 \mathrm{R}+3 \mathrm{R}\left(\mathrm{Mg} \mathrm{ha}{ }^{-1}\right.$ of millable stalks); TSH (Ave 4 crops), average sugar yield of $\mathrm{PC}+1 \mathrm{R}+2 \mathrm{R}+3 \mathrm{R}\left(\mathrm{Mg} \mathrm{ha}^{-1}\right.$ of sucrose), in which: PC, plant cane; ${ }^{\mathrm{n}} \mathrm{R}$, ratoons. 
of Orlando Filho et al. (1994), Korndörfer et al. (1997, 2002), and Trivelin et al. (2002).

Differently from other studies, the present work also considered the accumulated yields against all $\mathrm{N}$ treatments applied during the four evaluated cycles (2006-2009). The amount of accumulated $\mathrm{N}$ that maximized TCH was $420 \mathrm{~kg} \mathrm{ha}^{-1}$ and corresponded to $120-100 \mathrm{~kg} \mathrm{ha}^{-1}$ in plant cane and ratoons, respectively. Similarly, the accumulated dose of $440 \mathrm{~kg} \mathrm{ha}^{-1} \mathrm{~N}$, or $40-150 \mathrm{~kg} \mathrm{ha}^{-1}$ in plant cane and ratoons, also performed very close to this last one for both $\mathrm{TCH}$ and TSH (Figure 4).

Although $120 \mathrm{~kg} \mathrm{ha}^{-1} \mathrm{~N}$ is twice higher than the indicated dose for plant cane, Espironello et al. (1996) and Penatti \& Forti (1997) recommended this amount
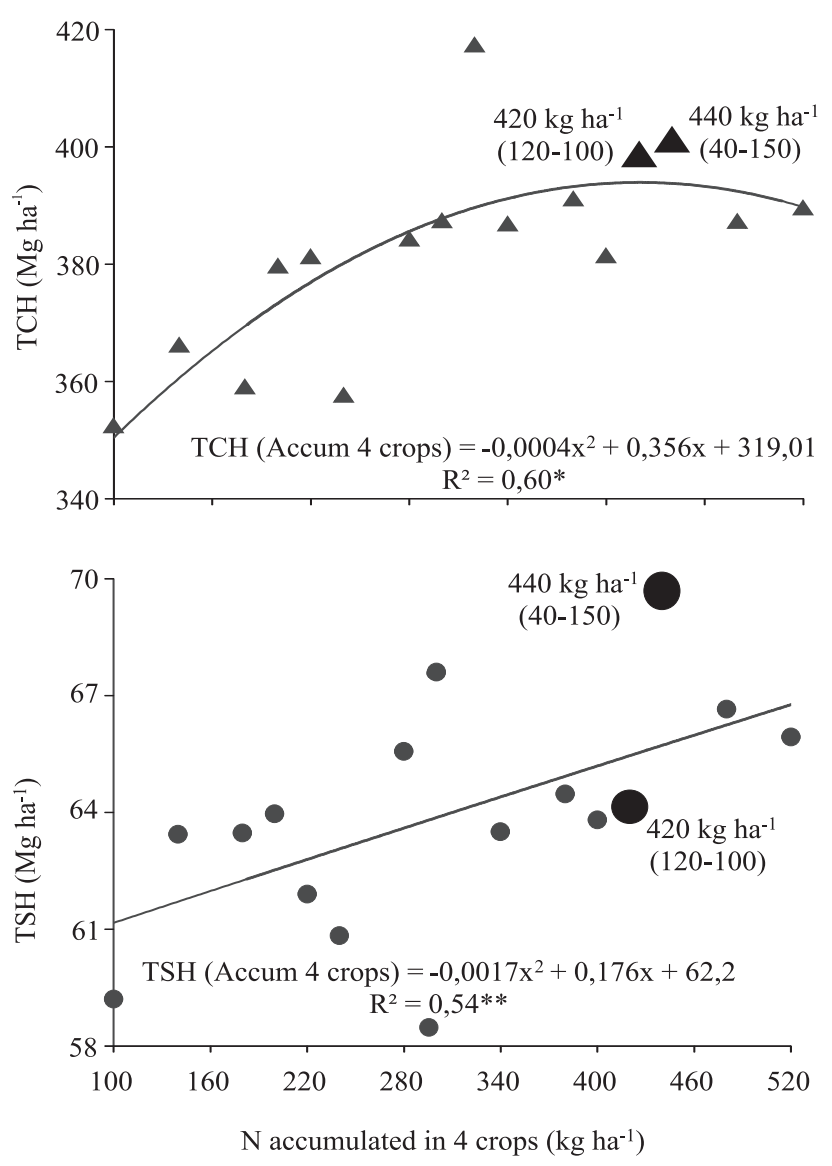

Figure 4. Accumulated agroindustrial yields and total $\mathrm{N}$ applied on sugarcane after four consecutive cycles (2006 to 2009). TCH (Accum 4 crops), accumulated crop yield of $\mathrm{PC}+1 \mathrm{R}+2 \mathrm{R}+3 \mathrm{R}\left(\mathrm{Mg} \mathrm{ha}^{-1}\right.$ of millable stalks); TSH (Accum 4 crops), average sugar yield of $\mathrm{PC}+1 \mathrm{R}+2 \mathrm{R}+3 \mathrm{R}\left(\mathrm{Mg} \mathrm{ha} \mathrm{h}^{-1}\right.$ of sucrose), in which: PC, plant cane; ${ }^{n} \mathrm{R}$, ratoons. of $\mathrm{N}$ for ratoon cane at that age and with the same expected TCH level, respectively. Wiedenfeld (1998) observed quadratic responses in the TCH of the second and third ratoons in Texas, after the same $\mathrm{N}$ doses $(0$, 50,100 , and $150 \mathrm{~kg} \mathrm{ha}^{-1}$ ) were applied, and concluded that maximum responses occurred between 100 and $150 \mathrm{~kg} \mathrm{ha}^{-1}$. In another field trial, this author found that the $\mathrm{N}$ rates that maximized $\mathrm{TCH}$ ranged between 140 and $175 \mathrm{~kg} \mathrm{ha}^{-1}$.

The above mentioned trials were conducted under the burned cane system, which could have also influenced the differences in sugarcane responses to $\mathrm{N}$ found in the present work. Rossetto et al. (2010) observed that, in the average of 15 trials of $\mathrm{N}$ and $\mathrm{K}$ fertilization under unburned sugarcane, the $\mathrm{N}$ level that provided the highest TCH was $150 \mathrm{~kg} \mathrm{ha}^{-1}$, but that an economic level should be of $120 \mathrm{~kg} \mathrm{ha}^{-1} \mathrm{~N}$, which is in agreement with the obtained results (Figures 2, 3, and 4). The fact that all plots were fertilized in the last ratoon did not interfere in the accumulated results as shown by Fortes (2010), who evaluated the cumulative yields on a yearly basis and reported the same trend of $\mathrm{N}$ rates in plant cane and ratoons.

Franco et al. (2011) observed that, in sugarcane under trash blankets, the $\mathrm{N}$ fertilizer is more important in the early development of sugarcane and that, after maturation and leaf senescence, part of the $\mathrm{N}$ accumulated by sugarcane is lost to the environment. Moreover, in reduced tillage, $\mathrm{N}$ and other nutrients available on crop residues are conserved on soil layers, since this system delivers a slow release source of $\mathrm{N}$ to sugarcane (Fortes et al., 2011).

\section{Conclusion}

Nitrogen fertilization in plant cane and ratoons promotes increases in agroindustrial production, millable stalks $(\mathrm{TCH})$, and sugar (TSH), during the crop cycles, both individually and in the accumulated production of four crops.

\section{Acknowledgements}

To Fundação de Amparo à Pesquisa do Estado de São Paulo (Fapesp), for financial support; to the São Martinho sugarmill and Centro de Tecnologia Canavieira (CTC), for providing the experimental site and other resources for the experiment. 


\section{References}

ALLEN, R.G.; PEREIRA, L.S.; RAES, D.; SMITH, M. Crop evapotranspiration: guidelines for computing crop water requirements. Rome: FAO, 1998. 300p. (FAO. Irrigation and drainage paper, 56).

BODDEY, R.M.; URQUIAGA, S.; ALVES, B.J.R.; REIS, V. Entophytic nitrogen fixation in sugarcane: present knowledge and future applications. Plant and Soil, v.252, p.139-149, 2003. DOI: 10.1023/A:1024152126541.

CANÇADO, J.E.D.; SALDIVA, P.H.N.; PEREIRA, L.A.A.; LARA, L.B.L.S.; ARTAXO, P.; MARTINELLI, L.A.; ARBEX, M.A.; ZANOBETTI, A.; BRAGA, A.L.F. The impact of sugar cane-burning emissions on the respiratory system of children and the elderly. Environmental Health Perspectives, v.114, p.725-729, 2006. DOI: 10.1289/ehp.8485.

CANTARELLA, H.; TRIVELIN, P.C.O.; VITTI, A.C. Nitrogênio e enxofre na cultura da cana-de-açúcar. In: YAMADA, T.; ABDALLA, S.R.S. e; VITTI, G.C. (Ed.). Nitrogênio e enxofre na agricultura brasileira. Piracicaba: IPNI, 2007. p.355-412.

CHAPOLA, R.G.; HOFFMANN, H.P.; BASSINELLO, A.I.; FERNANDES JUNIOR, A.R.; BRUGNARO, C.; ROSA, J.R.B.F.; VIEIRA, M.A.S.; SCHIAVINATO, S.R. Censo varietal de cana-de-açúcar de 2009 dos estados de São Paulo, Mato Grosso e Mato Grosso do Sul. STAB, v.28, p.34-37, 2010.

CONSELHO DOS PRODUTORES DE CANA-DE-AÇÚCAR, AÇÚCAR E ÁlCOOL DO ESTADO DE SÃO PAULO. Manual de instruções. 5.ed. Piracicaba: Consecana, 2006. 112p.

COPERSUCAR. Quinta geração de variedades de cana-de-açúcar. Piracicaba: Copersucar, 1995. (Boletim técnico).

DOURADO-NETO, D.; POWLSON, D.; ABU BAKAR, R.; BACCHI, O.O.S.; BASANTA, M.V.; CONG, P.T.; KEERTHISINGHE, G.; ISMAILI, M.; RAHMAN, S.M.; REICHARDT, K.; SAFWAT, M.S.A.; SANGAKKARA, R.; TIMM, L.C.; WANG, J.Y.; ZAGAL, E.; KESSEL, C. van. Multiseason recoveries of organic and inorganic nitrogen-15 in tropical cropping systems. Soil Science Society of America Journal, v.74, p.139-152, 2010. DOI: 10.2136/sssaj2009.0192.

ESPIRONELLO, A.; RAIJ, B. van; PENATTI, C.P.; CANTARELLA, H.; MORELLI, J.L.; ORLANDO FILHO, J.; LANDELL, M.G.A.; ROSSETTO, R. Cana-de-açúcar. In: RAIJ, B. van; CANTARELLA, H.; QUAGGIO, J.A.; FURLANI, A.M.C. (Ed.). Recomendações de adubação e calagem para o Estado de São Paulo. Campinas: Fundação IAC, 1996. p.237-239. (IAC. Boletim técnico, 100).

FORTES, C. Produtividade de cana-de-açúcar em função da adubação nitrogenada e da decomposição da palhada em ciclos consecutivos. 2010. 153p. Tese (Doutorado) - Universidade de São Paulo, Piracicaba.

FORTES, C.; TRIVELIN, P.C.O.; VITTI, A.C.; FERREIRA, D.A.; FRANCO, H.C.J.; OTTO, R. Recovery of nitrogen $\left({ }^{15} \mathrm{~N}\right)$ by sugarcane from previous crop residues and urea fertilisation under minimum tillage system. Sugar Tech, v.13, p.42-46, 2011. DOI: 10.1007/s12355-011-0074-4.
FRANCO, H.C.J.; OTTO, R.; FARONI, C.E.; VITTI, A.C.; OLIVEIRA, E.C.A.; TRIVELIN, P.C.O. Nitrogen in sugarcane derived from fertilizer under Brazilian field conditions. Field Crops Research, v.121, p.29-41, 2011. DOI: 10.1016/j. fcr.2010.11.011.

FRANCO, H.C.J.; TRIVELIN, P.C.O.; FARONI, C.E.; VITTI, A.C.; OTTO, R. Stalk yield and technological attributes of planted cane as related to nitrogen fertilization. Scientia Agricola, v.67, p.579-590, 2010. DOI: 10.1590/S0103-90162010000500012.

HEMWONG, S.; TOOMSAN, B.; CADISCH, G.; LIMPINUNTANA, V.; VITYAKON, P.; PATANOTHAI, A. Sugarcane residue management and grain legume crop effects on $\mathrm{N}$ dynamics, $\mathrm{N}$ losses and growth of sugarcane. Nutrient Cycling in Agroecosystems, v.83, p.135-151, 2009. DOI: $10.1007 /$ s10705-008-9209-8.

KORNDÖRFER, G.H.; COLOMBO, C.; CHIMELLO, M.A.; LEONE, P.L.C. Desempenho de variedades de cana-de-açúcar cultivadas com e sem nitrogênio. STAB, v.20, p.28-31, 2002.

KORNDÖRFER, G.H.; VALLE, M.R.; MARTINS, M.; TRIVELIN, P.C.O. Aproveitamento do nitrogênio da uréia pela cana planta. Revista Brasileira de Ciência do Solo, v.21, p.23-26, 1997.

LIU, J.; YOU, L.; AMINI, M.; OBERTSTEINER, M.; HERRERO, M.; ZEHNDER, A.J.B.; YANG, H. A high-resolution assessment on global nitrogen flows in cropland. Proceedings of the National Academy of Sciences of the United States of America, v.107, p.8035-8040, 2010. DOI: 10.1073/pnas.0913658107.

ORLANDO FILHO, J.; CARMELLO, Q.A.C.; PEXE, C.A.; GLÓRIA, A.M. Adubação de soqueiras de cana-de-açúcar sob dois tipos de despalha: cana crua x cana queimada. STAB, v.12, p.7-11, 1994.

ORLANDO FILHO, J.; RODELLA, A.A.; BELTRAME, J.A.; LAVORENTI, N.A. Doses, fontes e formas de aplicação de nitrogênio em cana-de-açúcar. STAB, v.17, p.39-41, 1999.

PENATTI, C.P.; FORTI, J.A. Doses de vinhaça versus doses de nitrogênio em cana-soca. In: SEMINÁRIO DE TECNOLOGIA AGRONÔMICA, 7., 1997, Piracicaba. Anais. Piracicaba: Copersucar, 1997. p.328-339.

RAIJ, B. van; ANDRADE, J.C.; CANTARELLA, H.; QUAGGIO, J.A. (Ed.). Análise química para avaliação da fertilidade de solos tropicais. Campinas: IAC, 2001. 285p.

ROSSETTO, R.; DIAS, F.L.F.; LANDELL, M.G.A.; CANTARELlA, H.; TAVARES, S.; VITTI, A.C.; PERECIN, D. $\mathrm{N}$ and $\mathrm{K}$ fertilisation of sugarcane ratoons harvested without burning. In: INTERNATIONAL SOCIETY OF SUGARCANE TECHNOLOGISTS CONGRESS, 27., 2010, Veracruz. Proceedings. Veracruz: ISST, 2010. v.27, p.1-8.

SANTOS, H.G. dos; JACOMINE, P.K.T.; ANJOS, L.H.C. dos; OLIVEIRA, V.A. de; OLIVEIRA, J.B. de; COELHO, M.R.; LUMBRERAS, J.F.; CUNHA, T.J.F. (Ed.). Sistema brasileiro de classificação de solos. 2.ed. Rio de Janeiro: Embrapa Solos, 2006. $316 \mathrm{p}$.

SOIL SURVEY STAFF. Keys to soil taxonomy. $10^{\text {th }}$ ed. Washington: USDA, 2006. 341p. 
STOLF, R. Cultivo mínimo para cana-de-açúcar. Boletim Técnico Planalsucar, v.6, p.5-42, 1985.

THORBURN, P.J.; BIGGS, J.S.; WEBSTER, A.J.; BIGGS, I.M. An improved way to determine nitrogen fertiliser requirements of sugarcane crops to meet global environmental challenges. Plant and Soil, v.339, p.51-67, 2011. DOI: 10.1007/s11104-010-0406-2.

TRIVELIN, P.C.O.; VITTI, A.C.; OLIVEIRA, M.W.; GAVA, G.J.C.; SARRIÉS, G.A. Utilização de nitrogênio e produtividade da cana-de-açúcar (cana-planta) em solo arenoso com incorporação de resíduos da cultura. Revista Brasileira de Ciência do Solo, v.26, p.637-646, 2002.

VITTI, A.C.; FRANCO, H.C.J.; TRIVELIN, P.C.O.; FERREIRA, D.A.; OTTO, R.; FORTES, C.; FARONI, C.E. Nitrogênio proveniente da adubação nitrogenada e de resíduos culturais na nutrição da cana-planta. Pesquisa Agropecuária
Brasileira, v.46, p.287-293, 2011. DOI: 10.1590/S0100204X2011000300009.

VITTI, A.C.; TRIVELIN, P.C.O.; GAVA, G.J.C.; PENATTI, C.P.; BOLOGNA, I.R.; FARONI, C.E.; FRANCO, H.C.J. Produtividade da cana-de-açúcar relacionada ao nitrogênio residual e do sistema radicular. Pesquisa Agropecuária Brasileira, v.42, p.249-256, 2007. DOI: 10.1590/S0100-204X2007000200014.

WIEDENFELD, R.P. Water stress during different sugarcane growth periods on yield and response to $\mathrm{N}$ fertilization. Agricultural Water Management, v.43, p.173-182, 2000. DOI: 10.1016/S0378-3774(99)00053-0.

WIEDENFELD, R.P. Previous-crop effects on sugarcane responses to nitrogen fertilization. Agronomy Journal, v.90, p.161-165, 1998. DOI: 10.2134/agronj1998.00021962009000020007x.

Received on August 2, 2012 and accepted on January 4, 2013 